\title{
PERAN SOSIAL DALAM PELAKSANAAN PENDIDIKAN AKHLAK
}

\author{
Sarah Rahmadika \\ Universitas Pendidikan Indonesia, Indonesia \\ *E-mail:sarahrahma3103@upi.edu
}

\begin{abstract}
The social community is very influential in the success of education in schools. Both are interrelated and cannot be separated from each other. The sociological contribution discussed here is about the role of the family, community and school in achieving the intended educational outcomes for students, namely students who have good character and excel in their schools. Moral education itself becomes the foundation for the formation of a good society. For this reason, it is necessary to know what patterns of interaction which can exist between the three parties and what are the roles of families and communities in educating students' morals. This research is qualitative in nature, the data collection techniques are carried out with literature studies and objects of the study is the implementation of moral education in schools and sociology which are tools for establishing good cooperation between the three components above. The results of this study state that there are two patterns of social interaction, namely formal and informal interactions. And the role of the family as well as the community for the implementation of moral education in schools is very important.
\end{abstract}

Keywords: Social Role, Moral Education, Social Interaction, Society

Abstrak. Masyarakat sosial sangat berpengaruh terhadap keberbasilan pendidikan di sekolah. Keduanya saling terkait dan tidake bisa dipisabkan satu dengan lainnya. Kontribusi sosiologi yang dibahas di sini adalah tentang peran keluarga, masyarakat dan sekolah dalam mencapai hasil pendidikan yang diinginkan bagi siswa, yaitu siswa yang berakblak baik dan berprestasi di sekolahnya. Pendidikan akblak sendiri menjadi pondasi untuke terbentuknya masyarakat yang baik. Untuk itu perlu di ketabui apa saja pola interaksi yang bisa terjalin di antara ketiga peran tersebut dan apa saja andil keluarga dan masyarakat dalam mendidik akblak siswa. Penelitian ini bersifat kualitatif, tehnike pengumpulan datanya dilakukan dengan studi pustaka dan objek kajiannya mengenai pelaksanaan pendidikan akblak di sekolah dan sosiologi yang menjadi alat terjalinnya kerjasama yang baik antara tiga komponen di atas. Hasil dari penelitian ini menyatakan bahwa ada dua pola interaksi sosial, yaitu interaksi formal dan informal. Dan peran keluarga dan masyarakat bagi pelaksanaan pendidikan akblak sangat penting.

Kata Kunci: Peran Sosial, Pendidikan Akblak, Interaksi Sosial, Masyarakat 


\section{PENDAHULUAN}

Keberhasilan Pendidikan bukan hanya tanggung jawab guru-guru dan pihak sekolah, melainkan tanggung jawab bersama antara seluruh komponen di lingkungan siswa. Pihak yang paling berwenang selain pihak sekolah adalah lingkungan keluarga dan masyarakat tempat siswa dibesarkan. Menurut sebuah penelitian mengatakan bahwa 50\% potensi seorang anak sudah tumbuh semenjak ia di dalam kandungan, hal ini berarti setengah dari karakter anak tumbuh di lingkungan keluarga, 30\% potensi lainnya akan tumbuh pada saat anak berusia 4-8 tahun, berarti akan tumbuh di lingkungan masyarakat dimana anak tinggal, dan 20\% potensinya akan berkembang saat anak tumbuh menjadi lebih dewasa.

Hal tersebut menyatakan bahwa sekolah hanya memiliki andil yang sedikit dalam mendidik siswa dibandingkan dengan peran keluarga dan masyarakat. Hasil dari proses yang paling diinginkan oleh semua komponen adalah terbentuknya sikap, kebiasaan atau akhlak yang baik pada siswa. Karena jika generasi penerus memiliki akhlak yang baik maka itu adalah awal dari terciptanya keluarga, masyarakat bahkan negara yang baik. Saat ini tidak sedikit orang yang memiliki kepintaran dan kecerdasan luar biasa di Indonesia, namun sayangnya hanya sedikit orang yang memiliki akhlak kebiasaan yang baik, padahal tujuan dasar pendidikan bukan hanya menargetkan kecerdasan intelektual, tapi juga kecerdasan spiritual.

Dalam rangka mewujudkan masyarakat yang berakhlak baik tersebut, maka bisa dikatakan bahwa tanggung jawab pendidikan adalah milik keluarga yang akan mendidik anak dalam bentuk pendidikan informal, tanggung jawab sekolah dalam bentuk pendidikan formal dan tanggung jawab masyarakat yang mendidik dalam bentuk pendidikan non formal (Surawardi 2015).

Untuk mewujudkan Pendidikan anak di ranah formal, maka diperlukan lembaga-lembaga pendidikan yang resmi seperti halnya sekolah. Lembaga pendidikan merupakan salah satu sistem yang memungkinkan berlangsungnya pendidikan secara berkesinambungan. Bahkan saling mempengaruhi antara satu dengan yang lainya dalam rangka mensukseskan tujuan pendidikan baik di rumah, sekolah maupun masyarakat. Tanggung jawab lembaga pendidikan tersebut dengan segala jenisnya menurut pandangan Islam adalah erat kaitanya dengan usaha menyukseskan sebagai seorang muslim. Oleh karenanya, dalam kajian pendidikan Islam pun pendidikan keluarga dan masyarakat mendapat perhatian yang sangat penting dan serius. (Surawardi 2015).

Dari penjelasan di atas dapat dikatakan bahwa ruang lingkup atau kajian sosiologi pendidikan berkisar antara masyarakat disekitarnya. Karena sebenarnya masyarakat juga melaksanakan fungsi pendidikan dengan pewarisan norma, nilai dan perilaku pada para anggotanya (Syaepurohman et al. 2010).

Untuk itu penulis mengangkat judul "Peran Sosiologi dalam Pelaksanaan Pendidikan Akhlak" dan berusaha mengangkat pembahasan tentang 
pentingnya kontribusi dan kerjasama yang harus dilakukan oleh sekolah, keluarga dan masyarakat untuk meghasilkan akhlak yang baik pada diri siswa. Serta peran apa saja yang bisa dilakukan oleh keluarga dan masyarakat untuk mengembangkan potensi anak ke arah yang baik dan akhirnya menciptakan akhlak yang baik pula. Penulis berpendapat bahwa Pendidikan akhlak di sekolah adalah hal yang paling mendasar untuk melihat keberhasilan proses Pendidikan secara umum. Disini juga akan disinggung tentang bagaimana pola interaksi yang bisa terjalin antara pihak keluarga, masyarakat dan sekolah untuk perkembangan siswa.

Peran sosial yang dimaksud disini adalah peranan yang dipegang oleh keluarga dan masyarakat untuk menyukseskan proses pendidikan, khususnya pendidikan akhlak. Sementara itu pengertian dari Sosiologi Islam yang menjadi landasan teori dalam penelitian ini adalah suatu disiplin keilmuan yang membekukan kajiannya di ranah kelompok masyarakat Islam. Sosiologi Islam berupaya memotret kelompok masyarakat Islam yang memiliki sistem budaya kemasyarakatan yang terbangun atas sistem nilai, keyakinan, historis, dan moralitas sendiri (Sampean, 2018).

Pengertian akhlak sendiri diungkapkan oleh al-Ghazali sebagai AlKhuluq (jamaknya Al-Akhlaq) ialah ibarat (sifat atau keadaan) dari perilaku yang konstan/ tetap dari padanya tumbuh perbuatan-perbuatan dengan wajar dan mudah, tanpa memerlukan pikiran dan pertimbangan (Indana, 2018). Akhlak merupakan salah satu dari tiga kerangka dasar ajaran Islam yang memiliki kedudukan yang sangat penting, di samping dua kerangka dasar lainnya. Akhlak mulia merupakan buah yang dihasilkan dari proses penerapan aqidah dan Syariah (Marzuki, 2009). Kemudian pengertian dari Pendidikan akhlak sendiri adalah suatu proses pembinaan yang dilakukan disekolah oleh guru kepada muridnya, dengan tujuan untuk menciptakan sikap, prilaku dan kebiasaan yang sesuai dengan ajaran agama Islam dalam diri siswa. Sementara Pendidikan akhlak disini adalah suatu proses pembelajaran yang berlangsung di sekolah, yang diajarkan guru kepada siswanya, dengan tujuan untuk mendidik siswa agar bertingkah laku seperti yang disyariatkan Islam.

Ada beberapa penelitian lain yang mengangkat tema sama dengan penelitian ini. Pertama adalah artikel berjudul Teori Sosiologi Islam (Kajian sosiologis terhadap konsep-konsep sosiologi dalam Alquran al-Karim) ditulis oleh Aam Abdussalam. Fokus penelitian tersebut terletak pada pengembangan teori sosiologi Islam yang diangkat dari Alquran. Kedua, penelitian yang ditulis oleh Suhada berjudul "Sosiologi Pendidikan dalam pembentukkan karakter". Hasil penelitian ini menjelaskan bahwa dalam ilmu sosiologi dipelajari banyak hal yang bisa mendukung pelaksanaan Pendidikan karakter atau akhlak, diantaranya adalah mengenai proses sosialisasi yang merupakan salah satu factor penting dalam membangun karakter bangsa dalam diri masyarakat. Ketiga, penelitian berjudul "Peran orangtua terhadap Pendidikan anak persfektif Pendidikan Islam" karya Junias Zulfahmi dan Sufyan 
dari Sekolah tinggi agama Islam Negeri Teungku Dirundeng Melulaboh. Artikel tersebut membahas tentang peranan orang tua dalam mendidik anaknya agar memiliki akhlak yang baik, dengan kata lain orang tua adalah orang yang paling berpengaruh pada perkembangan sikap seorang anak.

Keempat, penelitian dari Irhamna yang berjudul "Analisis tentang kendalakendala yang dihadapi orangtua dalam pembinaan akhlak dan kedisiplinan belajar siswa Madrasah Darussalam Kota Bengkulu”. Penelitian ini mengangkat pembahasan tentang apa saja kendala yang dihadapi oleh orang tua siswa dalam membina akhlak mereka, hal tersebut terjadi karena kurangnya pemahanan orangtua tentang tugasnya untuk membimbing akhlak siswa. Kelima, artikel yang ditulis oleh Tika Santika seorang mahasiswa prodi Pendidikan Luar sekolah Universitas Singaperbangsa Karawang yang berjudul "Peran Keluarga, Guru dan Masyarakat dalam Pembentukkan Karakter anak usia dini”. Penelitian tersebut berfokus pada peran 3 komponen inti (keluarga, guru dan masyarakat) dalam pembentukkan karakter anak pada usia dini.

Keenam, artikel berjudul Peran keluarga, Sekolah dan Masyarakat Dalam Pembentukkan Karakter Berkualitas yang ditulis oleh Jito Subianto, menjelaskan bahwa proses pembentukkan karakter siswa tidak mudah dan tentunya memerlukan waktu yang lama. Pembentukkan akhlak adalah sesuatu yang harus dilakukan secara kontinu dan di dukung oleh semua pihak. Ketujuh, artikel berjudul "Kontribusi Sosiologi Dalam Pengembangan Pendidikan Islam" karya Mohammad Ali, penelitiannya berfokus pada 2 langkah yang bisa mengembangkan proses Pendidikan Islam, pertama adalah pengembangan konsep-konsep teoritis dan kedua adalah pengayaan reflektif dari pengalaman. Kedelapan, artikel berjudul "Partisipasi Masyarakat Dalam Penyelenggaraan Pendidikan" karya Ahmad Zaini, Amrazi Zakso dan M.Syukri yang menganalisis tetang partisipasi masyarakat dalam penyelenggaraan Pendidikan, berkenaan denga Implementasi Managemen Berbasis Sekolah (MBS) yang di laksanakan di Sekolah Dasar Muhammadiyah 2 Pontianak.

Pada penelitian ini sendiri, fokusnya berada pada bentuk kontribusi dan peran yang dilakukan masyarakat untuk membantu keberhasilan proses Pendidikan Akhlak di sekolah. Selain itu juga penelitian ini membahas tentang pola interaksi antara masyarakat- sekolah dan keluarga-sekolah yang bisa meningkatkan akhlak baik siswa. Dengan demikian, maka terlihat jelas perbedaan diantara penelitian ini dengan beberapa penelitian sebelumnya. Disini juga terlihat bahwa penelitian ini akan menghasilkan sesuatu yang baru yang belum dibahas pada karya ilmiah sebelumnya.

Secara umum tujuan dari penulisan artikel ini sendiri adalah untuk mengetahui bagaimana peran masyarakat sosial dalam usaha terjalinnya Kerjasama antara masyarakat dan sekolah dalam pelaksanaan pendidikan akhlak. Secara khusus penelitian ini akan menganalisis tentang apa saja pola interaksi yang bisa dilakukan pihak keluarga dan masyarakat terhadap pihak sekolah, dan juga mengetahui apa bentuk kontribusi dari 
keluarga dan masyarakat dalam proses Pendidikan akhlak siswa di sekolah.

\section{METODE PENELITIAN}

Metode penelitian yang digunakan dalam penelitian ini adalah kualitatif. Objek penelitiannya adalah proses pelaksanaan Pendidikan akhlak di sekolah dan sosiologi yang menjadi alat penghubung antara masyarakat dan sekolah agar bisa bekerjasama untuk meningkatkan mutu akhlak siswa. Jenis datanya adalah data kualitatif karena menggunakan data yang ada di dalam dokumen dan penelitian sebelumnya.

Penelitian ini menggunakan tekhnik studi Pustaka atau study literature sebagai tekhnik pengumpulan datanya, Dimana penulis mengumpulkan beberapa karya tulis seperti jurnal, buku dan media cetak lainnya sebagai rujukan utama, lalu menghimpunnya dan mengkajinya sebagai sebuah penelitian yang baru. Tekhnik analisis data yang digunakan disini adalah deskriptif analisis. Pengertian dari metode deskriptif analitis menurut Sugiono yaitu suatu metode yang berfungsi untuk mendeskripsikan atau memberi gambaran terhadap objek yang diteliti melalui data atau sampel yang telah terkumpul sebagaimana adanya tanpa melakukan analisis dan membuat kesimpulan yang umum. Secara lengkapnya, metode deskriptif analitis yaitu suatu metode penelitian dengan mengungkapkan masalah yang ada, mengolah data, menganalisis, meneliti dan menginterprestasikan serta membuat kesimpulan dan memberi saran yang kemudian disusun pembahasannya secara sistematis (Sugiyono, 2009).

Penelitian ini melalui beberapa langkah hingga akhirnya menghasilkan suatu kesimpulan. Langkah pertama yang dilakukan dalam penelitian ini adalah mencari dan mengumpulkan data yang diperlukan sesuai dengan tema penelitian yang dipilih, data didapat dari berbagai sumber dokumen seperti artikel, buku, tesis, dan berbagai karya ilmiah lain. Kemudian Langkah selanjutnya adalah menganalisis data yang telah dikumpulkan. Kemudian menjabarkannya dalam bentuk paragrap dalam isi pembahasan artikel. Setelah itu Langkah terakhir yang dilakukan adalah menyimpulkan hasil penelitian dan pemberian saran untuk penulis selanjutnya yang akan membahas tema yang sama.

\section{HASIL PENELITIAN DAN PEMBAHASAN}

Manusia hakikatnya adalah makhluk bermasyarakat dan berbudaya. Namun karena manusia tidak secara otomatis mampu hidup bermasyarakat dan berbudaya, maka masyarakat melakukan pendidikan atau sosialisi (socialization) (Syatriadin, 2017).

Pendidikan merupakan media yang sangat efektif dalam membentuk dan membangun sikap dan pikiran serta kepribadian seseorang (Andi Anirah, 2007). Dengan Pendidikan seseorang bisa menjadi lebih baik dari segala aspek kehidupannya. Namun masih banyak masyarakat yang menganggap bahwa keberhasilan suatu Pendidikan adalah mutlak tanggung jawab sekolah, padahal 
pada dasarnya tanggung jawab Pendidikan adalah milik semua pihak yang berada di sekeliling siswa termasuk keluraga dan masyarakat. Dengan demikian, peran dan kontribusi sosial dalam proses Pendidikan menjadi sangat penting, hal ini dibahas secara mendalam dalam ilmu sosiologi khususnya dalam teori sosiologi Pendidikan.

Pengertian sosiologi Menurut Pidarta (1997:145), adalah ilmu yang mempelajari tentang hubungan antara manusia dalam kelompok-kelompok dan struktur sosialnya. Dengan kata lain, ilmu ini mempelajari tentang bagaimana individu (manusia) berhubungan dan berinteraksi dengan individu lain dalam kelompoknya (Kurniarahman, 2018).

Di dalam ilmu sosiologi sendiri akan dipelajari berbagai hal yang dapat mendukung pelaksanaan Pendidikan, khusunya dalam penelitian ini adalah Pendidikan akhlak. Peran itu dapat dimulai dengan mengenal proses sosialisasi, yang merupakan salah satu faktor penting untuk keberhasilan suatu proses Pendidikan (Suhada, 2020).

Sementara dasar atau landasan sosiologis adalah dasar yang memberikan kerangka sosiobudaya, yang mana dengan sosiobudaya itu pendidikan dilaksanakan. Dasar ini juga berfungsi sebagai tolak ukur dalam prestasi belajar. Artinya, tinggi rendahnya suatu pendidikan dapat diukur dari tingkat keselarasan output atau hasil pendidikan dengan kebutuhan masyarakat. Pendidikan yang baik adalah pendidikan yang tidak kehilangan konteks atau tercabut dari akar masyarakatnya. Prestasi pendidikan hampir tidak berguna jika prestasi itu merusak tatanan masyarakat. Demikian juga, masyarakat yang baik akan menyelenggarakan format pendidikan yang baik pula (Surawardi, 2015).

Program pendidikan disusun dan dipengaruhi oleh nilai, masalah, kebutuhan, dan tantangan dalam masyarakat. Masyarakat baik suatu sistem yang dapat memengaruhi proses pendidikan, oleh karena itu, dalam penyusunan kurikulum harus mempertimbangkan keterlibatan masyarakat. (Hamalik, 2008) (Saputri, 2020).

Dalam prakteknya, salah satu aspek yang menjadi sasaran utama pendidikan adalah terbentuknya budi pekerti luhur pada diri setiap peserta didik. Sebagai makhluk individu, manusia memiliki potensi (fitrah) yang dibawa sejak lahir dan sangat potensial untuk dapat dikembangkan. Potensi tersebut hanya dapat berkembang secara sempurna melalui proses pendidikan termasuk pendidikan akhlak (Johariyah, 2019).

Signifikasi pendekatan sosiologi dalam Pendidikan Islam, salah satunya adalah dapat memahami fenomena sosial yang berkenaan dengan ibadah dan muamalat. Pentingnya pendekatan sosiologis dalam memahami agama dapat dipahami karena banyak sekali ajaran agama yang berkaitan dengan masalah sosial (Zulfikar, 2010).

Dalam ranah agama Islam, landasan sosilogis bersinggungan dengan kata bablumminallâh dan hablumminannâs yang ada di dalam Islam. Dalam agama Islam sendiri konsep bablumminallâh dan bablumminannâs diartikan bukan sebagai dua hal yang mendua, melainkan dua 
yang menyatu. Artinya, interaksi sosial seseorang tidak netral dari nilai-nilai Ilahiyah. Ketika dia merealisasikan hubungan sosialnya kepada sesamanya, pada hakikatnya dia sedang mengaktualisasikan hubungan dengan Rabbnya. Dia akan memilih kata, sikap dan tindakan terbaik. Tidak saja terbaik menurut dirinya, tetapi juga terbaik menurut ukuran nilai-nilai Rabbnya (Abdussalam, 2014).

Dengan kesadaran akan pentingnya keterlibatan peran keluarga dan masyarakat dalam proses Pendidikan akhlak, maka perlu diketahui juga apa saja pola interaksi yang bisa dijalin oleh ketiga komponen tersebut dan juga peran apa saja yang bisa diambil oleh keluarga dan masyarakat untuk keberhasilan proses Pendidikan akhlak tersebut.

\section{A. Pola interaksi keluarga, masyarakat dan sekolah dalam pelaksanaan Pendidikan Akhlak}

Pola interaksi yang terjalin antara keluarga, masyarakat dan pihak sekolah bisa dipelajari dengan menggungakan teori sosiologi Pendidikan. Beberapa kajian yang masuk dalam sosiologi pendidikan adalah pola hubungan antara sistem pendidikan dengan masyarakat sosial dan perubahan yang ada di dalamnya (Daimah \& Pambudi, 2018).

Ada tiga jenis pola kegiatan sosial dalam pendidikan, yaitu (1) pola kegiatan sosial nomothetis yang merupakan pola kegiatan sosial yang lebih menekankan pada dimensi tingkah laku yang bersifat normatif, seperti pernyataan bahwa pendidikan adalah sosialisasi kepribadian; (2) pola kegiatan sosial ideografis adalah pola kegiatan sosial yang lebih menekankan pada dimensi tingkah laku yang bersifat individual/perseorangan; (3) Pola kegiatan sosial transaksional adalah pola kegiatan yang mengutamakan keseimbangan, dimana Pendidikan adalah suatu sistem sosial yang bersifat demokratis, (Setiasih, 2009:10).

Selain pola interaksi sosial yang bersifat umum, disini penulis juga melengkapinya dengan pembahasan sosiologi Islam yang berasal dari Alquran. Dalam sebuah jurnal dari Aam Abdussalam, beliau menulis bahwa ada 3 konsep dasar sosiologi islam dalam Al-Quran, yaitu tadafu', ta'aruf dan ta'awun.

Konsep tadafu' menunjukkan bahwa sifat saling menolak atau konflik merupakan ketetapan (hukum) Allah yang berlaku pada kehidupan manusia. Artinya, kehadiran tadafu' merupakan keharusan yang ada di dalam kehidupan manusia agar terlihat jelas mana yang merupakan kebenaran dan mana yang bukan. Tujuannya tiada lain agar terciptanya kehidupan masyarakat yang baik dan harmonis.

Selanjutnya konsep ta'aruf memiliki beberapa makna sekaligus. Setidaknya ada tiga makna pokok dari konsep tersebut: (1) adanya hubungan timbal balik (interaksi) antara satu pihak dan pihak lain; (2) hubungan atau interaksi tersebut terjadi atas dasar pengenalan atau pengetahuan yang benar; (3) interaksi yang terjadi menimbulkan hubungan dan 
kebersamaan yang harmoni di antara pihak-pihak yang terlibat.

Kemudian konsep yang dinamakan ta'awun. Konsep ini diangkat dari QS Al-Mâ'idah ayat 2 yang berbunyi. "Saling tolong menolonglah dalam kebajikan dan ketakwaan, dan janganlah saling tolong menolong dalam dosa dan permusuban". Konsep ini mengakui adanya perbedaan sekaligus mengakui bahwa setiap (individu) memiliki potensi dan kekuatan, sekecil apapun adanya. Konsep ini menghendaki agar perbedaan potensi dan kekuatan fungsional secara positif dalam membangun kehidupan bersama yang harmonis (Abdussalam, 2014).

Setelah membahas tentang pola interaksi yang umum dan pola interaksi Islam, penulis merangkumnya menjadi beberapa pola interaksi pokok yang bisa dilakukan oleh keluarga dan masyarakat kepada pihak sekolah dengan tujuan untuk menghasilkan siswa yang ber-akhlakul karimah. Secara umum, pola interaksi sosial-sekolah ini bisa dibedakan menjadi 2 macam, yaitu pola formal dan nonformal.

\section{Formal}

Pola interaksi ini memiliki prinsip Intergrity, coverage dan constractive. Integrity berarti terpadu yang dalam hal ini berarti bahwa semua kegiatan hubungan sekolah dan masyarakat harus terpadu. Artinya informasi yang disampaikan antar keduanya harus informasi yang tersusun mengenai hal akademik maupun non akademik. Pada nyatanya sering terjadi pihak sekolah tidak menginformasikan sesuatu yang sebenarnya menjadi masalah dan perlu bantuan atau dukungan orang tua murid.

Prinsip kedua yaitu coverage yang didalamnya berlangsung kegiatan pemberian informasi secara menyeluruh dan mencakup semua aspek yang perlu disampaikan dan perlu diketahui oleh masyarakat, misalnya program ekstrakurikuler, kegiatan kurikuler, remedian teaching, dan kegiatan lainnya.

Prinsip ketiga yaitu constactive atau program hubungan sekolah dengan masyarakat saling memberikan informasi yang membangun pemahaman dan pengetahuan masyarakat terhadap program pengembangan sekolah. Dengan demikian masyarakat akan memberikan respon positif tentang sekolah serta mengerti dan memahami secara detail berbagai masalah yang dihadapi sekolah. Apabila hal tersebut dapat dimengerti oleh masyarakat maka dapat menjadi salah satu faktor yang dapat mendorong mereka untuk memberikan bantuan kepada sekolah sesuai dengan permasalahan sekolah.

Pola interaksi ini cenderung mengandalkan pihak sekolah dalam penyampaian segala informasi mengenai pembelajaran siswa kepada masyarakat. Selain itu pola interaksi formal ini juga berorientasi pada penyampaian informasi yang luas, dengan tujuan agar masyarakat mengerti segala sesuatu hal yang terjadi di lingkungan sekolah. Pola ini memiliki waktu yang terjadwal dan bisa dilakukan secara berkala antara 
orangtua dan skateholder dengan saling bertukar informasi atau melaporkan segala kegiatan siswa. Biasanya pola interaksi ini direalisasikan dalam bentuk rapat tahunan orangtua dan pembentukkan komite sekolah.

Hal ini sangat penting untuk meningkatkan penilaian dan kepercayaan antar keduanya atau dengan kata lain transparansi sekolah sangat diperlukan (Afriansyah, 2019).

\section{Nonformal}

Pola interaksi ini memiliki prinsip Continue, simple dan adaptability. Continue berarti bahwa hubungan kerjasama antara masyarakat dan sekolah harus dilakukan secara terus menerus, hal ini dilakukan agar masyarakat mengetahui perkembangan sekolah. Jadi pelaksanaan hubungan sekolah dengan masyarakat tidak hanya dilakukan secara insedental.

Simple berarti interaksi ini menghendaki agar proses hubungan sekolah dan masyarakat ini berlangsung secara sederhana sehingga informasi yang disajikan kepada masyarakat bisa lebh mudah di terima dan sesuai dengan kondisi dan karakteristik masyarakat. Untuk praktiknya informasi dapat disajikan kepada masyarakat melalui pertemuan langsung maupun melalui media, dan hendaknya disajikan dalam bentuk sederhana sesuai dengan kondisi dan karakteristik pendengar. Prinsip kesederhanaan ini juga mengandung makna bahwa informasi yang disajikan dinyatakan dengan kata-kata yang penuh persahabatan dan mudah dimengerti.
Prinsip selanjutnya adalah adaptability. Yaitu program hubungan sekolah dengan masyarakat hendaknya disesuaikan dengan keadaan di dalam masyarakat. Penyesuaian dalam hal ini termasuk penyesuaian terhadap budaya, aktivitas, kebiasaan, dan informasi yang ada dan berlaku di dalam kehidupan masyarakat. Bahkan pelaksanaan kegiatan hubungan dengan masyarakat pun harus disesuaikan dengan kondisi masyarakat (Sagala, 2008).

Pola interaksi ini memiliki ciri-ciri sebagai berikut; terjadi secara terus menerus, tidak ada Batasan waktu tertentu dan lebih fleksible, tidak terbatas oleh momen tertentu, seperti rapat atau pertemuan formal lainnya, dan bisa berubah seiring perkembangan di masyarakat. Orangtua dan pihak sekolah dapat berkomunikasi dengan cara yang paling sederhana seperti saat bertemu dilingkungan sekolah.

Pola ini menekankan intensitas komunikasi yang tinggi, selain itu juga kesederhanaan dalam penyampaian, sehingga tidak ada rasa canggung dan formalitas diantara kedua pihak.

Disamping keberhasilan suatu Kerjasama antara beberapa pihak, tentunya adapula faktor yang bisa mendukung dan faktor penghambatnya. Dalam hal ini, ada beberapa hal yang bisa menjadikan interaksi masyarakat-sekolah berjalan dengan lancar.

Hal pertama adalah preposionalitas dari skateholder atau warga sekolah dari mulai kepala 
sekolah, guru-guru, petugas tata usaha dan seluruh warga yang ada di sekolah. Dengan adanya prefosionalitas maka setiap orang akan mengetahui apa saja tanggung jawab yang diembannya sebagai warga sekolah, dimana orang tua telah mempercayakan anaknya untuk mengikuti proses Pendidikan di sana. Hal kedua yaitu terjalinnya hubungan antara komite dan satuan Pendidikan. Hubungan ini bukan hanya berlangsung Ketika ada rapat sekolah atau pertemuan formal lainnya, namun komite dan sekolah harus bekerja sama agar segala informasi dan komunikasi tentang perkembangan belajar siswa dapat tersampaikan dengan sempurna. Hal terakhir yang bisa menjadi faktor pendukung adalah proses evaluasi hasil dari pihak sekolah kepada pihak orangtua dan masyarakat yang biasa dilaporkan dalam acara tahunan. Dengan adanya laporan tersebut, masyarakat social bisa mengetahui dan menilai seberapa jauh pencapaian yang dilakukan sekolah dalam usaha membina akhlak siswa. Dari hal itu juga masyarakat bisa mengetahui apa saja yang bisa dilakukan mereka untuk kontribusi pada proses Pendidikan akhlak selanjutnya (Zaini et al., 2014).

Disisi lain ada juga faktor penghambat yang menjadikan proses sosialisasi berjalan lebih lanbat dari seharusnya. Pertama adalah tingkat ekonomi masyarakat. Seperti yang kita ketahui bahwa tingkat ekonomi suatu masyarakat tentunya tidak sama. Untuk mamastikan proses Pendidikan anak berjalan dengan baik akan diperlukan dana yang tidak sedikit.
Orangtua harus mengeluarkan biaya untuk berbagai macam operasional yang di syaratkan oleh sekolah, selain itu orangtua juga harus membayar biaya fasilitas yang akan digunakan anak nya agar kualitas belajar semakin meningkat.

Namun pada kenyataannya tidak semua orangtua mampu dan mau untuk mengeluarkan materi bagi hal tersebut. Hal ini bisa di sebabkan oleh beberapa faktor, seperti tingkat pendapatan keluarga yang kurang mencukupi dan tingkat pemahaman orangtua akan pentingnya Pendidikan anak di sekolah.

Faktor penghambat yang kedua adalah taraf Pendidikan masyarakat yang juga beragam. Bagi masyarakat yang mengenyam Pendidikan tinggi akan lebih mudah memahami pentingnya Pendidikan dan bagaimana mereka harus berperan untuk kesuksesan Pendidikan anaknya. Namun banyak masyarakat yang memiliki tingkat Pendidikan rendah menganggap, bahwa dengan menyekolahkan anak saja sudah cukup untuk mengisi intelektual dan spiritual anak. masyarakat dengan tipe seperti ini cenderung tidak memperhatikan progress belajar anak dan juga menyalahkan sekolah jika anak tidak mendapat hasil yang mereka inginkan. Hal ini masih menjadi tantangan yang berat bagi pihak sekolah dalam pelaksanaan proses Pendidikan akhlak khususnya (Zaini et al., 2014).

Disamping hal diatas, masih
banyak hal sebenarnya yang
menghambat dalam pembinaan akhlak


peserta didik, karena bagaimana pun hari ini kita hidup di era globalisasi. Dimana akses teknologi begitu mudah dan canggih untuk digunakan atau disalahgunakan oleh peserta didik, sehingga teknologi itu pun akan memiliki dampak positif dan negative (Syaepul Manan, 2017).

\section{B. Peran Keluarga (dalam perencanaan, proses dan evaluasi hasil Pendidikan Akhlak)}

Keluarga merupakan tempat pertama dimana anak mendapatkan penanaman akhlak, dari sejak dalam kandungan, hingga dewasa. Dalam hal ini, peran orang tua menjadi sangat penting, karena dari orang tualah anak didik akan memperoleh pendidikan akhlak pertamanya (Putu, 2010). Selain itu kemajuan dan pertumbuhan serta perkembangan pribadinya juga sangat tergantung kepada kehidupan keluarga yang baik dan lingkungan yang aman (Sufyan, 2018)

Keterlibatan orang tua dan keluarga dalam pendidikan anak menjadi mutlak menjadi penyempurna dari nilai-nilai yang diajarkan di sekolah, sebab pendidikan anak (khususnya pendidikan akhlak) harus mengandung unsur afeksi atau kasih sayang, perasaan, sentuhan nurani, dan dipraktekkan dalam kehidupan seharihari (Masturin, 2015) (Miftahul, 2020).

Dalam prihal landasan pendidikan yang ditinjau dari sisi sosial, keluarga menjadi faktor paling utama dalam pelaksanaannya dan juga sebagai unit kecil dalam masyarakat. Kegiatan pendidikan dalam lembaga ini berlangsung tanpa ada suatu organisasi yang ketat. Tanpa ada program waktu dan evaluasi (Surawardi, 2015).

Fungsi keluarga menurut Djuju Sujana meliputi 7 hal, yaitu (1990: 20 22): 1) Fungsi Biologis; 2) Fungsi, Edukatif; 3) Fungsi Religius; 4)Fungsi Protektif; 5) Fungsi Sosialisasi; 6) Fungsi Rekreatif; dan 7) Fungsi Ekonomis (Santika, 2018).

Dalam istilah Islam, keluarga dikenal dengan istilah "usrah" dan" Nasb:, Sejalan dengan pengertian di atas, keluarga juga diperoleh lewat persusuan dan pemerdekaan. Keluarga merupakan lingkungan pertama, dimana kepribadian akan tumbuh dan terbentuk. Seorang akan menjadi warga masyarakat yang baik, bergantung pada lignkungan dimana ia dibesarkan (Surawardi, 2015).

Besarnya pengaruh orang tua dan keluarga dalam menentukan keberhasilan pendidikan anak, mengisyaratkan bahwa perhatian dan kesungguhan orang tua dalam mendidik anaknya merupakan prioritas utama dalam pendidikan akhlak (Zaitun, 2010). Orang tua adalah faktor penentu dalam pembentukkan akhlak anak. Lingkungan keluarga menjadi tempat pertama yang harus mengajarkan anak bersikap baik, membiasakan melakukan hal yang baik dan menjadi pengingat saat anak melakukan hal yang di luar syariat. Dengan kebiasaan seperti itulah akan terbentuk akhlak baik dan membantu proses pembentukkan akhlak yang akan dilanjutkan di ligkungan sekolahnya.

Untuk mewujudkan hasil Pendidikan akhlak yang diinginkan, orang tua bisa melakukan beberapa hal 
sebagai kontribusinya dalam Pendidikan anak. Hal tersebut diantara nya adalah: menanamkan keyakinan kepada Allah SWT, memberikan contoh dan teladan yang baik, memberikan perhatian, dan memberikan pengawasan, yang semuanya itu berada dalam lingkup pengertian dan pembiasaan (Wida, 2016).

Sidi Gazalba mengkategorikan keluarga sebagai jenis lembaga pendidikan primer, utamanya untuk masa bayi dan masa kanak- kanak sampai usia sekolah. Dalam lembaga ini sebagai pendidik adalah orang tua, kerabat, famili dan sebagainya. Orang tua selain sebagai pendidik, juga sebagai penanggung jawab. (Ramayulis, 2008: 282)

Masuk kedalam ranah Pendidikan akhlak, keluarga adalah pihak yang paling mempengaruhi berhasil atau tidak nya proses Pendidikan akhlak anak di sekolah. Anak yang tumbuh di keluarga yang disiplin, penuh kasih sayang dan perhatian akan menunjukkan sikap yang baik di sekolah, ia akan menghargai sesama temannya, mengerjakan kewajiban sekolah dan juga pencapaian prestasi yang memuaskan. Hal ini terjadi karna secara psikis, anak merasa percaya diri berada di lingkungan sekolah karena ia telah tumbuh di keluarga yang memiliki suasana menyenangkan. Hal ini juga berlaku sebaliknya, saat anak tumbuh di keluarga yang kurang kasih sayang dan perhatian, maka anak akan menunjukkan sikap dan prestasi yang kurang baik disekolah.

Untuk itu keluarga bisa ikut berpartisipasi untuk Pendidikan akhlak anak dalam 3 aspek, yaitu perencanaan Pendidikan, proses pelaksanaan Pendidikan dan evaluasi hasil Pendidikan.

Peran perencanaan diambil oleh orang tua dengan cara membangun komunikasi yang baik dengan guru atau pihak sekolah. Orang tua bisa menanyakan materi apa saja yang akan dipelajari oleh anak selama jangka waktu tertentu. selain itu proses pembelajaran yang akan dilakukan juga seharusnya diketahui oleh orang tua. Hal ini bisa dilakukan saat ada rapat orang tua, atau sekedar pertemuan informal antara orang tua dan pihak sekolah. Jika proses komunikasi ini berjalan dengan baik, maka akan memudahkan 2 pihak dalam proses selanjutnya yaitu proses pembelajaran.

Selain itu, salah satu tugas orang tua sebagai motivator terhadap anaknya. Motivasi yang diberikan sangat berperan penting dalam mendorong anak sehingga timbul keinginan untuk belajar. (Irhamna, 2019).

Keberhasilan keluarga dalam menanamkan nilai-nilai akhlak pada anak sangat tergantung pada jenis pola asuh yang diterapkan orang tua pada anaknya. Pola asuh juga dapat diartikan sebagai pola interaksi antara anak dengan orang tua. Ada beberapa pola asuh yang biasa diterapkan orangtua kepada anaknya: pertama, pola asuh otoriter, dimana orangtua mengatur segala aspek kehidupan anaknya dan tidak mendengarkan apa yang sebernarnya anak inginkan. Kedua, pola asuh demokratis, dimana pola asuh ini paling ideal di terapkan dalam keluarga, karena pola asuh 
demokratis bersifat tidak kaku dan juga mengakui anak sebagai individu yang memiliki keinginan tersendiri. Pola asuh ini menerapkan Kerjasama dan musyawarah antara anak dan orangtua. Ketiga, pola asuh permisif yaitu pola interaksi orangtua-anak yang di dominasi oleh anak. kontrol orangtua sama sekali tidak berpengaruh pada pola ini. Biasanya orangtua bersikap longgar kepada anaknya dan sangat sedikit perhatian yang diberikan dari orangtua kepada anak (Subianto, 2013). Dari penjelasan diatas dapat di ketahui bahwa pola asuh yang benar dari orangtua bisa berakibat baik untuk kecerdasan spiritual dan emotional anak. Disisi lain, jika pola asuh yang diberikan salah, maka hal itu juga akan berpengaruh pada kepribadian anak hingga ia dewasa.

Peran orangtua yang selanjutnya adalah dalam proses pembelajaran Pendidikan akhlak yang berlangsung disekolah, orangtua bisa menerapkan hal yang telah dipelajari siswa di sekolah di lingkungan rumah. Sebagai contoh, Ketika guru disekolah mengajarkan konsep jujur, maka orang tua bisa mempraktekkannya langsung dengan anak, hal ini bisa dilakukan dengan memberi tahu, mencontohkan dan membiasakan mengatakan hal-hal yang sebenarnya terjadi atau bukan kebohongan. Tentunya proses seperti ini tidak akan berlangsung sehari atau dua hari, hal ini perlu kesabaran orangtua. Setiap hal-hal baik harus dipaksakan pada awalnya hingga akhirnya menjadi kebiasaan. Dengan hal seperti itu lah orang tua berperan dalam proses pembelajaran

Pendidikan akhlak anak.

Ada beberapa metode pembinaan akhlak yang dapat dilakukan di lingkungan keluarga, diantaranya adalah: melalui contoh dan teladan yang diberikan orangtua dan orang di lingkungan keluarganya; metode nasehat; memberikan perhatian khusus dengan mencurahkan segala yang orangtua miliki seperti waktu, kasih sayang dan materi untuk membuat anak patuh; membiasakan melakukan hal yang baik, dengan kata lain orang tua tidak membiarkan anak berlaku seenaknya; memberikan hukuman sebagai jalan terakhir agar anak mau menuruti perintah orang tua (Sufyan, 2018).

Saat pembiasaan baik terus dilakukan bahkan di lingkungan rumah, anak akan terbiasa dan membawa kebiasaan baik itu kemanapun ia pergi. Disinilah orangtua berperan lagi dalam proses evaluasi Pendidikan akhlak yang telah diberikan. Orangtua bisa mengawasi bagaimana anak bergaul dengan teman-temannya dan bagaimana sikap anak diluar rumah. Hal ini sangat penting sebagai bahan evaaluasi dan tolak ukur keberhasilan dari kerjasama orangtua dan sekolah dalam membentuk akhlak seorang anak.

Epstein (2004: 10-14) dalam kerangka kerjanya yang dikenal dengan Epstein's Framework mengatakan terdapat enam bentuk kontribusi orang tua untuk Pendidikan anak di sekolah, pertama adalah bentuk parenting, yaitu membantu orang tua memahami perkembangan anak, serta memberikan gambaran pada orang tua 
di rumah memberikan pendidikan dan pengasuhan yang sinergi dengan yang diberikan oleh sekolah. Kedua yaitu communicating, yang bisa diartikan dengan merancang komunikasi yang efektif antara sekolah-rumah dan rumah-sekolah mengenai programprogram sekolah serta kemajuan dan perkembangan yang dialami anak. Ketiga yaitu volunteering, atau orang tua dapat menjadi relawan baik sebagai guru tamu, ataupun relawan yang dapat menyukseskan program sekolah dan aktivitas siswa di sekolah. Bentuk partisipasi selanjutnya dinamakan learning at Home, yaitu Ketika sekolah memberikan arahan dan bimbingan pada orang tua dalam membantu anak belajar di rumah, baik dalam mengerjakan tugas-tugas dari sekolah maupun kegiatan belajar yang dapat dilakukan di rumah. Kemudian selanjutnya adalah Decision-making, dimana orang tua disertakan dalam pengambilan keputusan di sekolah untuk membangun kepemimpinan orang tua dan perwakilan orang tua di sekolah. Dan bentuk partisipasi yang terakhir adalah collaborating with the community, yaitu dengan mengidentifikasi dan mengintegrasikan sumber daya dan jasa masyarakat untuk memberikan sumbangsih pada sekolah, memperkuat ketahanan sekolah, siswa, dan keluarga mereka (Miftahul, 2020).

\section{Peran Masyarakat (dalam perencanaan, proses dan evaluasi hasil Pendidikan akhlak)}

Masyarakat merupakan komunitas yang berbagi tanggung jawab untuk pendidikan mengembangkan karakter dan setia dan konsisten kepada nilai dasar yang diusung bersama-sama. Dalam lingkungan masyarakat terdapat sejumlah norma-norma yang harus dipatuhi bersama. Masyarakat merupakan media bagi peserta didik dalam berinteraksi dan bersosialisasi dengan sesamanya (Putu, 2010). Lingkungan masyarakat dinilai bisa membawa pengaruh negatif jika kebiasaan yang di terapkan di lingkungan tersebut adalah sesuatu yang buruk. Kebiasaan buruk tersebut dapat merubah pemahaman siswa tentang akhlak. Akhlak siswa bisa saja rusak atau berubah akibat pergaulan buruk yang diterimanya (Miftahul, 2019).

Hubungan antara pendidikan akhlak dengan masyarakat sangat erat. Hal ini dilihat lewat peranan pendidikan Islam dalam menyikapi fenomena sosial. (Andi Anirah, 2007). Sebuah teori dalam sosiologi berasumsi bahwa kehidupan masyarakat merupakan sebuah sistem besar yang terdiri atas sejumlah subsistem yang saling pengaruhi dan saling tergantung serta terintegrasi satu sama lain dalam membuat masyarakat itu berfungsi (Daimah \& Pambudi, 2018)

Pengaruh masyarakat terhadap sekolah sebagai suatu lembaga pendidikan sosial, sangat kuat, dan berpengaruh kepada para individu yang ada dalam lingkungan sekolah. Lingkungan sekolah merupakan masyarakat kompleks, terdiri dari berbagai macam tingkatan masyarakat yang saling melengkapi (Munir, 2016). 
Dalam dunia Pendidikan dikenal istilah school based management atau managemen sekolah yang berbasis sosial. Hal tersebut sering juga di sebut sebagai Pendidikan multicultural (Yuni, 2006). Beberapa ahli menyampaikan bahwa, Pendidikan multikultural ( istilah untuk pendidikan dengan berbasis pada masyarakat) adalah pendidikan untuk atau tentang keragaman kebudayaan dalam merespon perubahan demografis dan kultural lingkungan masyarakat tertentu bahkan dunia secara keseluruhan. Hal ini sejalan dengan pendapat Paulo Freire yang mengatakan bahwa pendidikan bukan merupakan menara gading yang berusaha menjauhi realitas sosial dan budaya. Tetapi menurutnya, pendidikan harus mampu menciptakan tatanan masyarakat yang hanya mengagungkan prestise sosial sebagai akibat kekayaan dan kemakmuran yang dialaminya (Maksum, 2013).

Ibn Qayyim seperti yang dikutip oleh Hasan Langgulung mengemukakan istilah tarbiyah ijtimaiyyah atau pendidikan kemasyarakatan. Menurutnya tarbiyah ijtimaiyyah yang membangun adalah yang mampu menghasilkan individu masyarakat yang saling mencintai sebagian dengan sebagian yang lainya, dan saling mendoakan walaupun mereka berjauhan dan antara anggota masyarakat harus menjalin persaudaraan. Dalam hal ini, ia mengingatkan dengan perkataan hikmah: orang yang cerdik adalah yang setiap harinya mendapatkan teman dan orang yang dungu adalah yang setiap harinya kehilangan teman. (Hasan Langgulung, 2003: 288).

Selain sebagai makhluk bermasyarakat, manusia juga merupakan makhluk berbudaya. Meski demikian, manusia tidak serta-merta bisa langsung hidup bermasyarakat dan berbudaya sejak lahir. Untuk itulah, individu atau masyarakat (dalam bentuk manusia) perlu melakukan kegiatan pendidikan (sosialisi). Hal ini dimaksudkan agar masing-masing individu bisa hidup bermasyarakat serta berbudaya, sehingga tingkah laku yang menyimpang dari nilai-nilai dan norma-norma di masyarakat bisa dihindari (Kurniarahman, 2018).

Proses pendidikan sendiri merupakan peristiwa sosial yang berlangsung dalam latar interaksi sosial. Dikatakan demikian, karena pendidikan tidak dapat dilepaskan dari upaya dan proses saling mempengaruhi antara individu yang terlibat di dalamnya. Dalam posisi yang demikian, apa yang dinamakan pendidik dan peserta didik, menunjuk kepada dua istilah yang dilihat dari kedudukannya dalam interaksi sosial. Artinya, siapa yang bertanggungjawab atas perilaku dan siapa yang memilki peranan penting dalam proses mengubahnya. Karena itu, proses pendidikan untuk menunjukkan siapa yang menjadi pendidik dan siapa yang menjadi peserta didik secara permanen, karena keduanya dapat saling berubah fungsi dan kedudukan (Savira Nurmalita, n.d.).

Dilihat dari bagaimana lingkungan masyarakat sangat berpengaruh 
terhadap kehidupan individu di dalamnya, maka masyarakat juga berperan penting dalam keberhasilan suatu proses Pendidikan, khususnya Pendidikan akhlak.

Peran pertama bisa dilakukan dalam proses perencanaan Pendidikan itu sendiri. Pada dasarnya, kurikulum yang ada disekolah harus disusun berdasarkan nilai, masalah, kebutuhan dan tantangan yang ada di masyarakat. Untuk itu saat merencanakan suatu proses Pendidikan, masyarakat harus dilibatkan, entah itu dengan cara mengundang perwakilan masyarakat dalam rapat sekolah, atau dengan membentuk system komite.

Selanjutnya dalam proses
pelaksanaan Pendidikan akhlak, masyarakat juga bisa membina individunya dengan menerapkan beberapa peraturan yang harus dipenuhi, hal itu bermaksud untuk menjadikan masyarakat lebih disiplin, dan terbiasa mematuhi peraturan yang berlaku. Norma-norma yang terdapat di masyarakat harus diikuti oleh warganya dan norma-norma itu berpengaruh dalam pembentukan akhlak warganya dalam bertindak dan bersikap (Santika, 2018). Sebagai contoh, pihak yang berwenang di masyarakat bisa menerapkan kebiasaan kerja bakti setiap minggu pagi. Bagi orang yang paling rajin berpartisipasi di dalamnya akan mendapat reward dan orang yang tidak pernah berpartipasi akan mendapat punishment bisa berupa denda atau yang lainnya. Aturan tersebut diterapkan agar setiap orang terbiasa hidup bersih dan mencintai kebersihan itu adalah salah satu nilai akhlak baik yang sering dipelajari di sekolah. Adapun hal lain yang bisa di dapat dari bersosialisasi dengan masyarakat adalah sikap saling menghargai, dimana individu tidak disarankan untuk melakukan control sosial dengan cara yang buruk. Misalkan, saat seseorang berbuat kesalahan, hal yang paling benar adalah mengingatkannya, bukan dengan bergosip atau melakukan sillent treatment.

Pada dasarnya apapun yang di terapkan di masyarakat harus berjalan beriringan dengan poin-poin akhlak yang dipelajari disekolah. Dengan cara seperti itulah kontribusi dan peran masyarakat untuk Pendidikan terlihat jelas.

Hal terakhir sebagai peran masyarakat dalam Pendidikan akhlak adalah evaluasi hasil. Pendidikan akhlak yang dilakukan masyarakat bisa terlihat hasilnya dari sikap anak dalam bersosialisasi. Proses evaluasi sendiri bukan dengan cara memberi nilai atau reward seperti yang di lakukan di sekolah, namun dengan melihat langsung respon masyarakat kepada seseorang. Masyarakat akan cenderung berprilaku baik kepada anak/ siswa yang sopan, menghargai orang tua dan berkata jujur. Sebaliknya masyarakat akan langsung tidak bersimpati kepada anak yang bersikap kasar dan tidak memiliki sopan santun. Dengan mengamati hal tersebut, maka akan diketahui bagaimana hasil Pendidikan akhlak kepada setiap individu.

Dari penjelasan diatas bisa
diketahui bahwa implikasi dari


landasan sosiologi terhadap pendidikan bisa dilihat dari: a) Pengembangan teori Pendidikan, b) tujuan pendidikan, c) kurikulum pendidikan, dan d) proses Pendidikan.

Sosiologi Pendidikan sebagai teori dasar yang di gunakan dalam penelititan ini bersifat sangat kontributif dalam pengembangan Pendidikan, khususnya Pendidikan akhlak. Karena sosiologi Pendidikan adalah alat yang diterapkan untuk memahami dan memecahkan permasalahan Pendidikan yang bersifat sosiologis (Ali, 2016).

\section{KESIMPULAN}

Hasil dari penelitian ini menyatakan bahwa terdapat 2 pola interaksi yang bisa digunakan pihak orangtua dan masyarakat terhadap proses Pendidikan akhlak yang ada di sekolah. Pola yang pertama yaitu interaksi formal dan pola yang kedua yaitu interaksi nonformal. Kedua pola tersebut sama-sama bisa meningkatkan kualitas Pendidikan siswa namun perbedaannya terdapat pada bentuk komunikasinya sendiri. Dimana interaksi formal diadakan didalam suatu forum dan di hadiri oleh banyak orang, sementara interaksi nonformal lebih bersifat fleksibel dan tidak terikat oleh waktu tertentu.

Hal kedua yang bisa disimpulkan dari penelitian ini adalah bentuk kontribusi yang dilakukan orangtua dan masyarakat untuk kesuksesan proses Pendidikan akhlak. Orangtua berperan sebagai pondasi utama dalam membentuk akhlak anak, sifatnya tidak formal dan mengutamakan sisi kasih sayang dalam perannya. Sementara masyarakat memegang peran yang lebih luas. Lingkungan masyarakat bisa menjadi system control social yang lebih kuat dengan menerapkan norma yang bisa membuat kualitas individunya meningkat.

Penelitian selanjutnya yang memiliki garis besar sama yaitu bisa mengembangkan konsep tentang pola interaksi sosial-sekolah menjadi hal yang lebih kompleks sehingga bisa membantu proses Pendidikan akhlak menjadi lebih efektif. Selain itu, bentuk kontribusi yang bisa dilakukan orangtua dan masyarakat juga tidak terbatas dengan hal yang telah dituliskan disini. Sebaliknya, hal itu bisa terus berkembang seiring kebutuhan dan keperntingan di masyarakat.

\section{REFERENSI}

Abdussalam, A. (2014). TEORI SOSIOLOGI ISLAM ( Kajian Sosiologis terhadap Konsep-konsep sosiologi dalam Alquran). Jurnal Pendidikan Agama Islam -Ta'lim, 12(1), 25-40.

Afriansyah, H. (2019). Administrasi Hubungan Sekolab dengan Masyarakat. $1-4$.

https://doi.org/10.31227/osf.io/cx tvz

Ali, M. (2016). Kontribusi sosiologi dalam pengembangan Pendidikan Islam. In Subuf (Vol. 28, Issue 1, pp. 1-12).

Andi Anirah. (2007). Pendidikan Islam Dalam Perspektif Sosio-Kultural. Jurnal Hunafa, 4(3), 237-248.

Daimah, D., \& Pambudi, S. (2018). Pendekatan Sosiologi Dalam Kajian Pendidikan Islam. Jurnal Pendidikan Islam, 9(2), 115-126. https://doi.org/10.22236/jpi.v9i2.1 
814

Indana, N. (2018). Tela'Ah Nilai-Nilai Pendidikan Akhlak Pada Kisah Sayyidati Khadijah Istri Rasulullah. $D A R \quad$ EL-ILMI: Jurnal Studi Keagamaan, Pendidikan Dan Humaniora, 5(1), 123-144.

Irhamna. (2019). Analisis Tentang Kendala-Kendala yang dihadapi Orang Tua dalam Pembinaan Akhlak dan Kedisiplinan Belajar Siswa Madrasah Darussalam Bengkulu. Al-Babtsu, 1(1), 57-65. https://ejournal.iainbengkulu.ac.id/i ndex.php/albahtsu/article/view/35 5

Johariyah. (2019). Pendidikan Islam Dalam Pembentukan Akhlak Anak. Ilmiah Islamic Resources, 16(1), 23-34.

Kurniarahman, I. (2018). Landasan Sosiologis Pendidikan dan Implementasinya di Sekolah dalam Nilai - nilai Keislaman.

Maksum, A. (2013). Sosiologi Pendidikan. In Sosiologi Pendidikan.

Marzuki, M. (2009). Pembinaan Akhlak Mulia Dalam Berhubungan Antar Sesama Manusia Dalam Perspektif Islam. Humanika, 9(1), 25-38. https://doi.org/10.21831/hum.v9i1 .3781

Miftahul, J. (2019). Peranan Guru Dalam Pembinaan Akhlak Mulia Peserta Didik Sulamul Ulum Dan Tpa AzZahra. Jurnal Ilmiah Pendidikan Madrasah Ibtidaiyah, 3(2), 137-165.

Miftahul, J. (2020). Partisipasi Orang Tua Dalam Meningkatkan Kualitas Pendidikan Dasar Anak. In Unnes (Vol. 21, Issue 1, pp. 1-9). https://doi.org/10.1016/j.tmaid.20 20.101607\%0Ahttps://doi.org/10.1 016/j.ijsu.2020.02.034\%0Ahttps://o nlinelibrary.wiley.com/doi/abs/10.1 111/cjag.12228\%0Ahttps://doi.org
/10.1016/j.ssci.2020.104773\%0Ahtt ps://doi.org/10.1016/j.jinf.2020.04. 011\%0Ahttps://doi.o

Munir, W. (2016). Managemen Hubungan Sekolah dan Masyarakat dalam Pendidikan. Jurnal Edukasi, 2(1), 18-29.

Putu, S. J. (2010). Peran Keluarga, Sekolah dan Masyarakat Dalam Implementasi Pendidikan Tri Kaya Parisudha Sebagai Landasan Pembentukan Karakter Generasi Muda. Proceeding Seminar Nasional, 135.

http://proceedings.jayapanguspress. org/index.php/sembada2017/articl e/view/178

Sampean, S. (2018). Sosiologi Islam: Refleksi Atas Keberagamaan Umat Islam Di Indonesia Antara Dogma, Ajaran, Dan Realitas. Journal of Islamic World and Politics, 2(2), 18. https://doi.org/10.18196/jiwp.2223

Santika, T. (2018). Peran Keluarga, Guru Dan Masyarakat Dalam Pembentukan Karakter Anak Usia Dini. JUDIKA (Jurnal Pendidikan UNSIKA), 6(November), 77-86. https://journal.unsika.ac.id/index.p hp/judika/article/download/1797/ 1444

Saputri, rima Y. (2020). Implementasi Landasan Sosiologis dalam Pengembangan Kurikulum Muatan Lokal Berbasis Keagamaan di SMA N 1 Pleret Bantul. Jurnal Pendidikan Islam Al-Ilmi, 3(2), 80-94.

Savira Nurmalita. (n.d.). HAKIKAT PENDIDIKAN DAN LANDASAN PENDIDIKAN DALAM PROSES PEMBELAJARAN.

Subianto, J. (2013). Peran Keluarga, Sekolah, Dan Masyarakat Dalam Pembentukan Karakter Berkualitas.

TARBAWY: Indonesian Journal of Islamic Education - Vol. 8 No. 1 (2021) | 66 
Edukasia: Jurnal Penelitian Pendidikan

Islam, 8(2), 331-354.

https://doi.org/10.21043/edukasia.

v8i2.757

Sufyan, J. Z. \&. (2018). Peran Orang Tua Terhadap Pendidikan Anak Perspektif Pendidikan Islam. Bidayah: Studi Ilimu-Imu Keislaman, 9(1), 4964.

Suhada. (2020). Sosiologi Pendidikan Dalam Pembentukan Karakter (Sudut Pandang Sosial). Al-Amin: Jurnal Kajian Ilmu Dan Budaya Islam, 3(1), 113-121. doi.org/10.36670/alamin.v2i02.20

Surawardi. (2015). Dasar-Dasar Sosiologis Pendidikan Islam. Jurnail Guidanceand Counseling, 1(2), 55-68.

Syaepul Manan. (2017). Pembinaan Akhlak Mulia Melalui Keteladanan dan Pembiasaan. Jurnal Pendidikan Agama Islam-Ta'lim, XV(2), 1.

Syatriadin. (2017). Landasan Sosiologis Dalam Pendidikan. JISIP, 1(2), 101207.

Wida, A. (2016). Peran Orang Tua Dalam Mendidik Akblak Anak di Desa Bangun Jaya Kecamatan Sungkai Utara Lampung Utara (p. 2016).

Yuni, sasmita afiati. (2006). Urgensi Peran Serta Masyarakat Dalam Meningkatkan Mutu Pendidikan Sebagai Implementasi Konsep School Based Management.

Zaini, A., Zakso, A., \& Syukri, M. (2014). Partisipasi Masyarakat Dalam Penyelenggaraan Pendidikan. Jurnal Pendidikan Dan Pembelajaran, 3(11), 1-13. https://media.nelti.com

Zaitun. (2010). Sosiologi Pendidikan (Teori dan Aplikasinya). In Jakarta: Rineka Cipta.

Zulfikar, A. B. S. (2010). Pendekatan Sosiologis Dalam Studi Islam. Sosio- 